\title{
Non-invasive assessment of liver fibrosis in chronic hepatitis $\mathbf{C}$
}

\author{
Laurent Castera
}

Received: 21 September 2010/Accepted: 16 December 2010/Published online: 20 January 2011

(C) Asian Pacific Association for the Study of the Liver 2011

\begin{abstract}
Quantification of hepatic fibrosis is of critical importance in chronic hepatitis $\mathrm{C}$ not only for prognosis, but also for antiviral treatment indication. Two end points are clinically relevant: detection of significant fibrosis (indication for antiviral treatment) and detection of cirrhosis (screening for eosphageal varices and hepatocellular carcinoma). Until recently, liver biopsy was considered the reference method for the evaluation of liver fibrosis. Limitations of liver biopsy (invasiveness, sampling error, and inter-observer variability) have led to the development of non-invasive methods. Currently available methods rely on two different approaches: a "biological" approach based on the dosage of serum fibrosis biomarkers; and a "physical" approach based on the measurement of liver stiffness, using transient elastography (TE). This review is aimed at discussing the advantages and limits of noninvasive methods and liver biopsy and the perspectives for their rational use in clinical practice in the management of patients with chronic hepatitis C.
\end{abstract}

Keywords Chronic hepatitis C - Liver fibrosis . Non-invasive · Transient elastography · FibroScan . Serum biomarkers · Liver biopsy

L. Castera ( $₫)$

Service d'Hépatologie, Hôpital Beaujon, AP-HP, Université Denis Diderot Paris-VII, Clichy, France e-mail: laurent.castera@bjn.aphp.fr

\section{Introduction}

In patients with chronic hepatitis $\mathrm{C}$, precise staging of liver fibrosis is important not only for estimation of prognosis, but also for indication of antiviral therapy. Two end points are clinically relevant: detection of significant fibrosis, which is an indication for antiviral treatment, and detection of cirrhosis, which is an indication for specific monitoring of complications related to portal hypertension and to the increased risk of developing hepatocellular carcinoma [1].

Liver biopsy has traditionally been considered the reference method for the evaluation of liver fibrosis in chronic hepatitis $\mathrm{C}$ [2]. However, liver biopsy is an invasive procedure, associated with pain in around $30 \%$ of cases [3-5], and potentially life-threatening complications (hemorrhage in $0.3 \%$ of cases and mortality in $0.01 \%$ ) [6]. The accuracy of liver biopsy to assess fibrosis has also been questioned in relation to sampling errors and intra- and inter-observer variability that may lead to over- or under-staging [7-10]. Finally, liver biopsy does not allow dynamic evaluation of liver fibrosis over time.

These limitations have led to the development of noninvasive methods [11]. Currently available methods rely on two different, but complementary, approaches: [1] a "biological" approach based on the dosage of serum biomarkers of fibrosis; and [2] a "physical" approach based on the measurement of liver stiffness, using transient elastography (TE) [12]. Although the large number of publications over the past decade confirms the growing interest regarding these new non-invasive methods, there is a need for clarification and guidance on their use and interpretation. This review is aimed at discussing the advantages and limits of these methods, and the perspectives for their rational use in clinical practice in the management of patients with chronic hepatitis $\mathrm{C}$. 


\section{Biological approach: serum fibrosis biomarkers}

Individual surrogate serum markers of liver fibrosis

A variety of "direct" serum markers of fibrosis, reflecting either the deposition or the removal of extracellular matrix in the liver have been evaluated for their ability to assess liver fibrosis. These include: glycoproteins, such as serum hyaluronate [13-17], laminin [18, 19], and YKL-40 [20]; the collagens family, such as procollagen III N-peptide (PIIINP) [13] and type IV collagen [21]; collagenases and their inhibitors, such as matrix metalloproteases (MMP) [22] and tissue inhibitory metalloprotease-1 (TIMP-1) [23].

"Indirect" serum markers including simple routine blood tests, such as prothrombin index [19], platelet count [24], and AST/ALT ratio [25-27] have also been proposed.

The performances of "direct" and "indirect" serum markers have been evaluated in chronic hepatitis $\mathrm{C}$ (reviewed in [12, 28-30]), with hyaluronate being the most extensively studied. Apart from hyaluronate [14, 15, 31], "direct" and "indirect" markers, when used individually, are useful for the diagnosis or the exclusion of cirrhosis, but have limited accuracy for the diagnosis of significant fibrosis [32].

\section{Scores combining indirect and direct markers of liver fibrosis}

The limitations of individual markers to assess liver fibrosis have led to the development of more sophisticated scores combining the results of panels of markers that substantially improved diagnostic accuracy for which the FibroTest has been the pioneer [33]. Several other scores have been developed since then [34-48] (Table 1). The diagnostic performances for significant fibrosis and cirrhosis of proposed scores are summarized in Tables 2 and 3 , respectively.

Five scores are protected by patents and are currently commercially available: the FibroTest ${ }^{\circledR}$ in Europe (Biopredictive, Paris, France) licensed under the name of Fibrosure $^{\circledR}$ in the USA (LabCorp, Burlington, NC, USA), the Fibrometers ${ }^{\circledR}$ (BioLiveScale, Angers, France), the FibroSpectII $^{\circledR}$ (Promotheus Laboratory Inc. San Diego, Ca, USA), the ELF $^{\circledR}$ (Enhanced Liver Fibrosis Test, iQur Ltd, Southampton, UK), and the Hepascore ${ }^{\circledR}$ (PathWest, University of Western Australia, Australia).

To date, FibroTest ${ }^{\circledR}$ and aspartate to platelet ratio index (APRI) have been the most extensively studied. In a metaanalysis [49], which pooled 6,378 subjects (with analysis of individual data in 3,282) with both FibroTest and biopsy $(3,501 \mathrm{HCV})$, the mean standardized area under the ROC curve (AUROC) for diagnosing significant fibrosis was
0.84 (95\% CI, 0.83-0.86). In another meta-analysis [50], which pooled 4,266 $\mathrm{HCV}$ patients from 22 studies, the mean AUROCs of APRI for diagnosing significant fibrosis and cirrhosis were $0.76(0.74-0.79)$ and $0.82(0.79-0.86)$, respectively.

When compared and validated externally in patients with hepatitis C [51-56], the different patented scores have similar performances for the diagnosis of significant fibrosis. In the largest study to date $(n=1,307)$ [56], comparing prospectively several patented and non-patented scores (FibroTest ${ }^{\circledR}$, Fibrometre ${ }^{\circledR}$, Hepacore ${ }^{\circledR}$ and APRI), the AUROCs ranged from 0.72 to 0.78 for significant fibrosis and from 0.77 to 0.86 for cirrhosis. Although nonpatented scores, such as the Forns index, FIB-4, and APRI may have slightly lower performance, they are cost-free, easy to calculate, and available almost everywhere.

\section{Limitations}

One of the main limitations to the clinical use of "direct" markers of liver fibrosis is that they are not routinely available in most hospital settings. Another limitation of these markers is that none is liver-specific and they may be influenced by changes in their clearance and excretion. For instance, increased levels of hyaluronate occur in the postprandial state [57] or in aged patients with chronic inflammatory processes such as rheumatoid arthritis. Also, the reproducibility of measurement of some parameters included in "indirect" serum markers, such as AST levels or platelet count, is questionable [58]. Conversely, the inter-laboratory reproducibility of scores, such as FibroTest $^{\circledR}$ and Fibrometers ${ }^{\circledR}$ has been shown to be satisfactory for use in clinical practice [59-61]. However, when using FibroTest $^{\circledR}$, the interpretation should be done critically, taking into account each of the five components individually to avoid false-positive results related to hemolysis (decrease in haptoglobin) and Gilbert syndrome (increase in bilirubin), or false-negative results related to inflammation [62].

\section{Physical approach: transient elastography}

\section{Principle}

TE (FibroScan ${ }^{\circledR}$, Echosens, Paris, France) has been proposed for the measure of liver stiffness [63]. Briefly, an ultrasound transducer probe is mounted on the axis of a vibrator. Vibrations of mild amplitude and low frequency are transmitted by the transducer, inducing an elastic shear wave that propagates through the underlying tissues. Pulse-echo ultrasound acquisitions are used to follow the propagation of the shear wave and to measure 
Table 1 Proposed serum scores for non-invasive evaluation of liver fibrosis in chronic hepatitis C

- Fibrotest $^{\circledR}(\alpha$-2-macroglobulin, $\gamma \mathrm{GT}$, apolipoprotein A1, haptoglobin, total bilirubin, age, and gender)

- Forns Index (age, platelet count, cholesterol, and $\gamma \mathrm{GT}$ )

- AST to platelet ratio (APRI) (AST and platelet count)

- FibroSpect ${ }^{\circledR}$ ( $\alpha$-2-macroglobulin, hyaluronate, and TIMP-1)

- MP3 (MMP-3 and TIMP-1)

- Enhanced Liver Fibrosis score ${ }^{\circledR}$ (ELF) (age, hyaluronate, MMP-3, and TIMP-1)

- Fibrosis Probability Index (FPI) (age, past alcohol intake, AST, cholesterol, and HOMA-IR)

- Lok Index (platelet count, AST/ALT ratio, and INR)

- Gotebörg University Cirrhosis Index (GUCI) (AST, INR, and platelet count)

- Hepascore ${ }^{\circledR}$ (bilirubin, $\gamma \mathrm{GT}$, hyaluronate, $\alpha$-2-macroglobulin, age, and gender)

- Fibrometers ${ }^{\circledR}$ (platelet count, prothrombin index, AST, $\alpha$-2-macroglobulin, hyaluronate, urea, and age)

- Virahep-C model (AST, platelet count, alkaline phosphatase, and age)

- Fibroindex (platelet count, AST, and $\gamma$-globulin)

- FIB-4 (Platelet count, ALT, and AST)

- HALT-C model (hyaluronic acid, TIMP-1, and platelet count)

Table 2 Diagnostic performance of non-invasive serum scores of liver fibrosis for significant fibrosis in chronic hepatitis C

\begin{tabular}{|c|c|c|c|c|c|c|c|c|c|}
\hline Scores & Year & Patients $(n)$ & $\begin{array}{l}\text { Significant } \\
\text { fibrosis }(\%)\end{array}$ & Cutoffs & AUROC & $\mathrm{Se}$ & Sp & $+\mathrm{LR}$ & $-\mathrm{LR}$ \\
\hline FibroTest ${ }^{\circledR}[33]$ & 2001 & 339 & 80 & $>0.48$ & 0.87 & 75 & 85 & 5 & 0.3 \\
\hline Forns Index [34] & 2002 & 476 & 26 & $<4.2>6.9$ & $0.76-0.86$ & $30-94$ & $51-95$ & $1.9-6.0$ & $0.1-0.7$ \\
\hline APRI [35] & 2003 & 270 & 50 & $\leq 0.5>1.5$ & $0.69-0.88$ & $41-91$ & $47-95$ & $1.7-8.2$ & $0.2-0.6$ \\
\hline FibroSpect $^{\circledR}$ [36] & 2004 & 696 & 52 & $>0.36$ & 0.83 & 77 & 73 & 2.9 & 0.3 \\
\hline MP3 [37] & 2004 & 194 & 45 & $<0.3>0.4$ & 0.82 & $35-65$ & $85-96$ & $4.3-8.8$ & $0.4-0.7$ \\
\hline $\operatorname{ELF}^{\circledR}[38]$ & 2004 & $1,021^{\mathrm{a}}$ & 40 & NA & 0.78 & 90 & 30 & 1.3 & 0.3 \\
\hline FPI [39] & 2005 & 302 & 48 & $<0.2 \geq 0.8$ & 0.77 & $42-85$ & $48-98$ & $1.6-21.0$ & $0.3-0.6$ \\
\hline Hepascore $^{\circledR}[40]$ & 2005 & 211 & 57 & $\geq 0.5$ & 0.82 & 63 & 89 & 5.7 & 0.4 \\
\hline Fibrometer $^{\circledR}$ [41] & 2005 & $598^{\mathrm{b}}$ & 56 & NA & 0.89 & 80 & 84 & 5 & 0.2 \\
\hline ViraHep-C [42] & 2006 & 859 & 37 & $\leq 0.22>0.55$ & 0.83 & $51-90$ & $54-90$ & $2.0-5.1$ & $0.2-0.5$ \\
\hline Fibroindex [43] & 2007 & 360 & 50 & $\leq 1.25 \geq 2.25$ & 0.83 & $30-40$ & $97-97$ & $10.0-13.3$ & $0.6-0.7$ \\
\hline
\end{tabular}

AUROC Area under ROC curve, Se sensitivity, $S p$ specificity, $+L R$ positive likelihood ratio, $-L R$ negative likelihood ratio, $N A$ not available

a $496 \mathrm{HCV}$ patients; ${ }^{\mathrm{b}} 383$ with viral hepatitis in the exploratory population and $120 \mathrm{HCV}$ in the validation population

Table 3 Diagnostic performance of serum non-invasive scores of liver fibrosis for cirrhosis in chronic hepatitis C

\begin{tabular}{|c|c|c|c|c|c|c|c|c|c|}
\hline Scores & Year & Patients $(n)$ & Cirrhosis (\%) & Cut-offs & AUROC & $\operatorname{Se}(\%)$ & $\mathrm{Sp}(\%)$ & $+\mathrm{LR}$ & $-\mathrm{LR}$ \\
\hline FibroTest $^{\circledR}[56]$ & 2001 & 1,197 & 14 & $>0.74$ & 0.82 & 63 & 84 & 4 & 0.4 \\
\hline APRI [35] & 2003 & 476 & 17 & $<1.0 \geq 2.0$ & 0.94 & $57-89$ & $75-93$ & $3.6-8.1$ & $0.1-0.5$ \\
\hline Glycocirrhotest [44] & 2004 & $106^{\mathrm{a}}$ & $45^{\mathrm{b}}$ & NA & 0.87 & 79 & 86 & 5.6 & 0.2 \\
\hline $\operatorname{ELF}^{\circledR}[38]$ & 2004 & $1,021^{\mathrm{c}}$ & NA & NA & 0.89 & 91 & 69 & 2.9 & 0.4 \\
\hline Lok Index [45] & 2005 & 1,141 & 38 & $<0.2 \geq 0.5$ & 0.81 & $40-98$ & $53-99$ & $2.1-40.0$ & $0.04-0.6$ \\
\hline Hepascore $^{\circledR}[40]$ & 2005 & 211 & 16 & $>0.84$ & 0.89 & 71 & 89 & 6.5 & 0.3 \\
\hline GUCI [46] & 2005 & 179 & 12 & $>1.0$ & 0.85 & 80 & 78 & 3.6 & 0.3 \\
\hline FIB-4 [47] ${ }^{\mathrm{d}}$ & 2007 & 847 & $17 \$$ & $<1.45>3.25$ & 0.85 & $38-74$ & $81-98$ & $3.9-19.0$ & $0.3-0.6$ \\
\hline HALT-C model [48] & 2008 & 512 & 38 & $<0.2>0.5$ & 0.81 & $47-88$ & $45-92$ & $1.6-5.9$ & $0.3-0.6$ \\
\hline
\end{tabular}

AUROC Area under ROC curve, Se sensitivity, $S p$ specificity, + LR positive likelihood ratio, - LR negative likelihood ratio, NA not available

a $71 \mathrm{HCV}$ patients; ${ }^{\mathrm{b}} 24 \%$ with decompensated cirrhosis; ${ }^{\mathrm{c}} 496 \mathrm{HCV}$ patients; ${ }^{\mathrm{d}} \mathrm{F} 3 \mathrm{~F} 4$ patients 
its velocity, which is directly related to tissue stiffness of the elastic modulus: the stiffer the tissue, the faster the shear wave propagates. TE measures liver stiffness in a volume that approximates a cylinder of $1-\mathrm{cm}$ wide and 4-cm long, between 25 and $65 \mathrm{~mm}$ below the skin surface. This volume is at least 100 times bigger than a biopsy sample and is therefore far more representative of the hepatic parenchyma. TE is painless, rapid (less than $5 \mathrm{~min}$ ), and easy to perform at the bedside or in the outpatient clinic. The results are immediately available and expressed in kilopascals $(\mathrm{kPa})$, corresponding to the median value of ten validated measurements and range from 2.5 to $75 \mathrm{kPa}$ [64], with normal values around $5.5 \mathrm{kPa}[65]$.

\section{Reproducibility}

Reproducibility is an important prerequisite for a widespread application of TE in clinical practice. TE reproducibility has been shown to be excellent for both inter-observer and intraobserver agreement, with intra-class correlation coefficients (ICC) of 0.98 [66, 67]. However, inter-observer agreement was significantly reduced in patients with lower degrees of hepatic fibrosis, with hepatic steatosis, and with increased body mass index [66], as well as for liver stiffness values $<9 \mathrm{kPa}[67]$.

\section{Diagnostic performance}

The two index studies suggesting the interest of TE in the assessment of liver fibrosis were conducted in patients with chronic hepatitis C $[68,69]$. Many other groups have confirmed these results [56, 70-72] with a strong correlation of liver stiffness values with Metavir fibrosis stages and AUROCs ranging from 0.75 to 0.91 for the diagnosis of significant fibrosis and from 0.90 to 0.98 for cirrhosis. Cutoff values with optimal diagnostic accuracy were defined for each stage of fibrosis (Tables 4, 5). It should be stressed, however, that despite high AUROC values, a substantial overlap of liver stiffness values was observed between adjacent stages of hepatic fibrosis, particularly for lower fibrosis stages.

Three meta-analyses recently addressed the issue of diagnostic performance of TE [73-75]. In the most comprehensive meta-analysis, based on 50 studies (15 full papers and 35 abstracts) [75], the mean AUROC was 0.84 (95\% confidence interval (CI), 0.82-0.86) for the diagnosis of significant fibrosis with a suggested optimal cutoff of $7.6 \mathrm{kPa}$, and 0.94 (95\% CI, 0.93-0.95) for the diagnosis of cirrhosis with a suggested optimal cutoff of $13.0 \mathrm{kPa}$. Meta-analyses with individual data are awaited.

TE appears to be a reliable method for the diagnosis of cirrhosis, better at excluding than at predicting cirrhosis. For instance, in a population of 1,007 patients with different chronic liver diseases, a cutoff value of $14.6 \mathrm{kPa}$ yielded positive and negative predictive values of 74 and $96 \%$, respectively [76].

\section{Monitoring of disease progression}

Another promising application of TE is for monitoring the progression of liver fibrosis. The clinical significance of the wide range of liver stiffness values observed in patients with cirrhosis (13-75 kPa) remains uncertain. Preliminary results suggested that liver stiffness values in cirrhotic patients increased as the liver disease progressed [77]. For instance, cutoff values of 27.5, 37.5, 49.1, 53.7, and $62.7 \mathrm{kPa}$, respectively, had $>90 \%$ negative predictive value for the presence of stage $2 / 3$ esophageal varices, Child-Pugh score B or C, and a past history of ascites, $\mathrm{HCC}$, and esophageal bleeding. Although retrospective and conducted in a single centre, this study provided the first "proof of concept" that liver stiffness values may have prognostic value in a context of cirrhosis. In addition, several studies [78, 79] have shown a correlation between liver stiffness values and portal hypertension diagnosed by means of hepatic venous pressure gradient (HVPG) measurement, the gold standard for the diagnosis and staging of portal hypertension and a reliable predictor of clinical decompensation [80]. A correlation between liver stiffness

Table 4 Diagnostic performance of transient elastography for significant fibrosis in chronic hepatitis C

\begin{tabular}{|c|c|c|c|c|c|c|c|c|}
\hline Authors & Patients $(n)$ & $\begin{array}{l}\text { Significant } \\
\text { fibrosis }(\%)\end{array}$ & Cutoffs (kPa) & AUROC & $\operatorname{Se}(\%)$ & $\mathrm{Sp}(\%)$ & $+\mathrm{LR}$ & $-\mathrm{LR}$ \\
\hline Degos et al. [56] & 913 & 62 & 5.2 & 0.75 & 90 & 32 & 1.3 & 0.3 \\
\hline Sporea et al. [72] & 191 & 84 & 6.8 & 0.77 & 60 & 93 & 8.6 & 0.4 \\
\hline Castera et al. [69] & 183 & 74 & 7.1 & 0.83 & 67 & 89 & 6.1 & 0.4 \\
\hline Lupsor et al. [71] & 324 & 65 & 7.4 & 0.86 & 76 & 84 & 4.8 & 0.3 \\
\hline Arena et al. [70] & 150 & 56 & 7.8 & 0.91 & 83 & 82 & 4.6 & 0.2 \\
\hline Ziol et al. [68] & 251 & 65 & 8.6 & 0.79 & 56 & 91 & 6.6 & 0.5 \\
\hline
\end{tabular}

AUROC Area under ROC curve, $S e$ sensitivity, $S p$ specificity, $+L R$ positive likelihood ratio, $-L R$ negative likelihood ratio 
Table 5 Diagnostic performance of transient elastography for cirrhosis in chronic hepatitis C

\begin{tabular}{|c|c|c|c|c|c|c|c|c|}
\hline Authors & Patients $(n)$ & Cirrhosis (\%) & Cutoffs (kPa) & AUROC & $\operatorname{Se}(\%)$ & $\mathrm{Sp}(\%)$ & $+\mathrm{LR}$ & $-\mathrm{LR}$ \\
\hline Lupsor et al. [71] & 324 & 21 & 11.9 & 0.94 & 87 & 91 & 9.7 & 0.1 \\
\hline Castera et al. [69] & 183 & 25 & 12.5 & 0.95 & 87 & 91 & 9.7 & 0.1 \\
\hline Castera et al. [83] & 298 & 23 & 12.5 & 0.96 & 83 & 95 & 16.6 & 0.2 \\
\hline Degos et al. [56] & 913 & 14 & 12.9 & 0.9 & 72 & 89 & 6.8 & 0.3 \\
\hline Ziol et al. [78] & 251 & 19 & 14.6 & 0.97 & 86 & 96 & 23.1 & 0.1 \\
\hline Arena et al. [70] & 150 & 19 & 14.8 & 0.98 & 94 & 92 & 11.3 & 0.1 \\
\hline
\end{tabular}

AUROC Area under ROC curve, $S e$ sensitivity, $S p$ specificity, $+L R$ positive likelihood ratio, $-L R$ negative likelihood ratio

values and the presence of esophageal varices has also been reported [79, 81-84]. However, liver stiffness measurement (LSM) cannot yet confidently predict the presence of esophageal varices in clinical practice and thus avoid the need for upper GI endoscopic screening of cirrhotic patients [85].

TE could be also valuable for assessing the severity of recurrent hepatitis $\mathrm{C}$ after liver transplantation, reducing the need for follow-up liver biopsies [78, 86-90]. It has been recently suggested that TE may perform better for significant fibrosis than serum (direct and indirect) biomarkers [91].

Finally, TE could be useful for evaluating fibrosis regression in patients with chronic hepatitis $\mathrm{C}$ achieving sustained viral eradication [92-94] or for monitoring fibrosis progression in untreated patients.

Long-term prospective follow-up studies are now awaited to see whether liver stiffness values can predict the occurrence of clinical events in patients with compensated cirrhosis. Interestingly, a recent Japanese prospective study has shown in a large cohort of patients with chronic hepatitis $\mathrm{C}$ a correlation between liver stiffness values and the risk of hepatocellular carcinoma [95]. Although these findings need to be confirmed in other settings (Caucasian patients or HBV-infected patients) and with longer followup, they suggest that TE could be used as a rapid screening tool to allocate cirrhotic patients to specific risk categories [96].

\section{Limitations}

The interpretation of TE results should be always in the hands of an expert clinician and should be made having at disposition information regarding patient demographics, disease etiology, and essential laboratory parameters, as well as carefully following the manufacturer's recommendations (number of valid shots $\geq 10$; success rate (the ratio of valid shots to the total number of shots) $\geq 60 \%$; and interquartile range (IQR, reflecting the variability of measurements) less than $30 \%$ of the median LSM value (IQR/ $\mathrm{LSM} \leq 30 \%$ ) [64]). Indeed, in a recent prospective 5-year study based on more than 13,000 examinations, LSM failure (no value after ten measurements or more) has been shown to occur in $3.1 \%$ of cases and LSM results to be uninterpretable (not meeting manufacturer's recommendations) in an additional $15.8 \%$ [97]. Limited operator experience, obesity, and more generally features of the metabolic syndrome were the main determinants of LSM failure or unreliable results. This challenges previous claims [67, 98] that LSM requires no learning curve and that a novice can consistently obtain reliable results after a short training period. Operator experience influenced not only the success rate, as previously reported [67, 98], but also the IQR/LSM ratio, which was recently shown to be critical for LSM accuracy [99]. These findings emphasize the need for rigorous scientific evaluation of all novel procedures, such as TE before their widespread uptake. Further technological refinements are required for specific populations, such as those with the metabolic syndrome.

Finally, as the liver is an organ wrapped in a distensible but non-elastic envelope (Glisson's capsula), additional space-occupying tissue abnormalities, such as edema and inflammation, cholestasis and congestion may interfere with LSM, independently of fibrosis. Indeed, as previously mentioned, the extent of necro-inflammatory activity has been shown to influence TE measurements in patients with viral hepatitis with a steady increase of liver stiffness values in parallel with the degree of histological activity $[66,70,100]$. Consistent with these results, the risk of overestimating liver stiffness values has been reported in case of ALT flares in patients with acute viral hepatitis or chronic hepatitis B [101-103], as well as in cases of extrahepatic cholestasis [104] or congestive heart failure [105].

\section{Comparison and combination of approaches}

For the diagnosis of significant fibrosis, performances of TE and serum biomarkers have been shown to be equivalent in patients with chronic hepatitis $C$ [56, 69]. For the diagnosis of cirrhosis, the situation is different as TE 
appears to be the most accurate non invasive method in HCV patients when compared with currently available biomarkers and routine blood tests [56, 69], allowing the avoidance of liver biopsy in around $90 \%$ of cases. TE is thus "the test to be beaten" for those developing alternative methods [106].

In order to increase diagnostic accuracy, new approaches using a combination of TE and serum markers [69, 107, 108] have been proposed. For instance, using an algorithm to evaluate the agreement between TE and FibroTest $^{\circledR}$, liver biopsy can be avoided for the diagnosis of significant fibrosis in around $75 \%$ of patients with chronic hepatitis C [69].

Also, a sequential algorithm (SAFE Biopsy), using APRI as screening test, followed by Fibrotest ${ }^{\circledR}$ in APRI non-classified cases and restricting liver biopsy to patients classified as F0-F1 by non-invasive tests, has been proposed, allowing avoidance of liver biopsy for the diagnosis of significant fibrosis in around 50\% of cases [109]. These results have been confirmed in a large-scale, multicenter international validation study of more than 2,000 patients with chronic hepatitis C [110]. Other groups have proposed alternative algorithms combining FibroTest ${ }^{\circledR}$ and APRI [53] either with Forns index (Fibropaca) [111] or Hepascore [112].

In a recent study where these two approaches were compared in the same population of patients with chronic hepatitis $\mathrm{C}$, the number of saved liver biopsies was significantly higher using the combination of TE and Fibrotest ${ }^{\circledR}$ than SAFE Biopsy algorithm for detecting significant fibrosis (72 vs. $48 \%$, respectively; $P<0.0001$ ) [113].

A combination of two unrelated methods, such as TE and Fibrotest ${ }^{\circledR}$, may have certain advantages over the combination of two biomarkers, in that TE provides more direct measurement of the liver structure than serum markers and that there is no relationship between the applicability of TE (success rate and interquartile range) and Fibrotest ${ }^{\circledR}$ (Gilbert's syndrome, hemolysis, and sepsis) [107].

\section{Novel imaging techniques}

New alternative imaging techniques may also become available: magnetic resonance (MR) elastography, which can be implemented readily on standard MR imaging systems with additional hardware; diffusion weighted MR imaging, which measures the apparent diffusion coefficient of water, a parameter that is dependent on the tissue structure; optical digital analysis of computed tomography images of the liver and sonography-based real-time elastography, which can be performed with conventional ultrasound probes during a routine sonography examination
[114]. The theoretical advantages of these methods include the ability to analyze almost the entire liver and the applicability to patients with obesity or ascites. Preliminary studies in human subjects have confirmed the feasibility of these techniques for quantitative assessment of hepatic fibrosis [115-119]. In addition, a recent prospective comparative study in 96 patients with chronic liver disease [120] has suggested that MR elastography had a better diagnostic accuracy than TE for the diagnosis of significant fibrosis (AUROC: 0.99 vs. 0.84 , respectively $P<0.05$ ). Although such results are encouraging, these techniques remain so far too expensive and time-consuming for implementation in clinical practice for screening hepatic fibrosis.

Very recently, a novel imaging technology (ARFI acoustic radiation force impulse imaging), involving the mechanical excitation of tissue using short-duration $(\sim 262$ $\mu \mathrm{s})$ acoustic pulses producing shear waves propagation generating localized micron-scale displacements in the tissue, has been proposed [121]. The shear wave velocity (expressed in meters per second) is measured in a region of interest smaller than that of TE (10-mm long and 6-mm wide), but that can be chosen by the examiner. Preliminary results suggest that at least in patients with chronic hepatitis $\mathrm{C}$, its performance is very similar to that of TE, although further validation is warranted [122-126]. The major advantage of this novel technology is that it can be easily implemented on a modified commercial ultrasound machine. However, as compared with LSM values $(2.5-75 \mathrm{kPa})$, ARFI values are in a very narrow range $(0.5-4.4 \mathrm{~m} / \mathrm{s})$, which could represent a limitation to its use for making decision in clinical practice. More data are also awaited regarding the intra- and inter-observer reproducibility of ARFI.

\section{Conclusion}

Significant progress has been made in the non-invasive diagnosis of hepatic fibrosis in patients with chronic hepatitis C. An increasing number of reliable tests are now available: TE, Fibrotest ${ }^{\circledR}$ and APRI have been the most extensively studied and validated. These tests are already widely used in routine clinical practice in France resulting in a significant decrease in the need for liver biopsy [127]. However, it is likely that non-invasive methods will reduce but not completely abolish the need for liver biopsy [28]. The most rational way of using these tools is to make a compromise: use non-invasive methods to classify those patients in whom they perform with high accuracy, limiting liver biopsy to the subset of patients in whom precise noninvasive staging is not possible. In that respect, the use of TE and several patented scores (FibroTest ${ }^{\circledR}$, Fibrometer $^{\circledR}$, 
and Hepascore ${ }^{\circledR}$ ) has been recently approved, after an independent systematic review by the French Health Authorities, for the first-line assessment of fibrosis in naive patients with chronic hepatitis $\mathrm{C}$ without co-morbidities [128]. Interpretation of the results of non-invasive methods should always be done critically by an expert clinician according to clinical context and taking into account patient demographics, essential laboratory parameters, and manufacturer's recommendations. Apart from cases where cirrhosis is clinically obvious, a combination of two unrelated methods should be used rather than a single method. A liver biopsy should be performed in case of discordance between results of non-invasive tests, when non-invasive methods are not applicable, or if co-morbidities such as alcoholism or metabolic syndrome are present. In any case, a large specimen (ideally $20-25 \mathrm{~mm}$ ) should be obtained and reading should be done by an experienced liver pathologist.

In conclusion, we believe that liver biopsy and noninvasive methods, particularly TE, should be employed as an integrated system to allow a more efficient and convenient management of patients with chronic hepatitis $\mathrm{C}$ [129].

\section{References}

1. Ghany MG, Strader DB, Thomas DL, Seeff LB. Diagnosis, management, and treatment of hepatitis $\mathrm{C}$ : an update. Hepatology 2009;49:1335-1374

2. Bravo AA, Sheth SG, Chopra S. Liver biopsy. N Engl J Med 2001;344:495-500

3. Cadranel JF, Rufat P, Degos F. Practices of liver biopsy in France: results of a prospective nationwide survey. For the Group of Epidemiology of the French Association for the Study of the Liver (AFEF). Hepatology 2000;32:477-481

4. Castera L, Negre I, Samii K, Buffet C. Pain experienced during percutaneous liver biopsy. Hepatology 1999;30:1529-1530

5. Castera L, Negre I, Samii K, Buffet C. Patient-administered nitrous oxide/oxygen inhalation provides safe and effective analgesia for percutaneous liver biopsy: a randomized placebocontrolled trial. Am J Gastroenterol 2001;96:1553-1557

6. Piccinino F, Sagnelli E, Pasquale G, Giusti G. Complications following percutaneous liver biopsy. A multicentre retrospective study on 68,276 biopsies. J Hepatol 1986;2:165-173

7. Bedossa $P$, Dargère $D$, Paradis V. Sampling variability of liver fibrosis in chronic hepatitis C. Hepatology 2003;38:1449-1457

8. Regev A, Berho M, Jeffers LJ, Milikowski C, Molina EG, Pyrsopoulos NT, et al. Sampling error and intraobserver variation in liver biopsy in patients with chronic HCV infection. Am J Gastroenterol 2002;97:2614-2618

9. Rousselet MC, Michalak S, Dupre F, Croue A, Bedossa P, SaintAndre JP, et al. Sources of variability in histological scoring of chronic viral hepatitis. Hepatology 2005;41:257-264

10. Bedossa P, Carrat F. Liver biopsy: the best, not the gold standard. J Hepatol 2009;50:1-3

11. Castera L, Pinzani M. Non-invasive assessment of liver fibrosis: are we ready? Lancet 2010;375:1419-1420
12. Pinzani M, Vizzutti F, Arena U, Marra F. Technology insight: noninvasive assessment of liver fibrosis by biochemical scores and elastography. Nat Clin Pract Gastroenterol Hepatol 2008;5:95-106

13. Guechot J, Laudat A, Loria A, Serfaty L, Poupon R, Giboudeau J. Diagnostic accuracy of hyaluronan and type III procollagen amino-terminal peptide serum assays as markers of liver fibrosis in chronic viral hepatitis $\mathrm{C}$ evaluated by ROC curve analysis. Clin Chem 1996;42:558-563

14. McHutchison JG, Blatt LM, de Medina M, Craig JR, Conrad A, Schiff ER, et al. Measurement of serum hyaluronic acid in patients with chronic hepatitis $\mathrm{C}$ and its relationship to liver histology. Consensus Interferon Study Group. J Gastroenterol Hepatol 2000;15:945-951

15. Halfon P, Bourliere M, Penaranda G, Deydier R, Renou C, Botta-Fridlund D, et al. Accuracy of hyaluronic acid level for predicting liver fibrosis stages in patients with hepatitis $\mathrm{C}$ virus. Comp Hepatol 2005;4:6

16. Walsh KM, Fletcher A, MacSween RN, Morris AJ. Basement membrane peptides as markers of liver disease in chronic hepatitis C. J Hepatol 2000;32:325-330

17. Wong VS, Hughes V, Trull A, Wight DG, Petrik J, Alexander GJ. Serum hyaluronic acid is a useful marker of liver fibrosis in chronic hepatitis C virus infection. J Viral Hepat 1998;5:187192

18. Pilette C, Rousselet MC, Bedossa P, Chappard D, Oberti F, Rifflet $\mathrm{H}$, et al. Histopathological evaluation of liver fibrosis: quantitative image analysis vs semi-quantitative scores. Comparison with serum markers. J Hepatol 1998;28:439-446

19. Oberti F, Valsesia E, Pilette C, Rousselet MC, Bedossa P, Aube $\mathrm{C}$, et al. Noninvasive diagnosis of hepatic fibrosis or cirrhosis. Gastroenterology 1997;113:1609-1616

20. Saitou Y, Shiraki K, Yamanaka Y, Yamaguchi Y, Kawakita T, Yamamoto N, et al. Noninvasive estimation of liver fibrosis and response to interferon therapy by a serum fibrogenesis marker, YKL-40, in patients with HCV-associated liver disease. World J Gastroenterol 2005;11:476-481

21. Murawaki Y, Koda M, Okamoto K, Mimura K, Kawasaki H. Diagnostic value of serum type IV collagen test in comparison with platelet count for predicting the fibrotic stage in patients with chronic hepatitis C. J Gastroenterol Hepatol 2001;16:777-781

22. Murawaki Y, Ikuta Y, Idobe Y, Kawasaki H. Serum matrix metalloproteinase-1 in patients with chronic viral hepatitis. J Gastroenterol Hepatol 1999; 14:138-145

23. Boeker KH, Haberkorn CI, Michels D, Flemming P, Manns MP, Lichtinghagen R. Diagnostic potential of circulating TIMP-1 and MMP-2 as markers of liver fibrosis in patients with chronic hepatitis C. Clin Chim Acta 2002;316:71-81

24. Pohl A, Behling C, Oliver D, Kilani M, Monson P, Hassanein T. Serum aminotransferase levels and platelet counts as predictors of degree of fibrosis in chronic hepatitis $\mathrm{C}$ virus infection. Am $\mathrm{J}$ Gastroenterol 2001;96:3142-3146

25. Imperiale TF, Said AT, Cummings OW, Born LJ. Need for validation of clinical decision aids: use of the AST/ALT ratio in predicting cirrhosis in chronic hepatitis C. Am J Gastroenterol 2000;95:2328-2332

26. Park GJ, Lin BP, Ngu MC, Jones DB, Katelaris PH. Aspartate aminotransferase: alanine aminotransferase ratio in chronic hepatitis C infection: is it a useful predictor of cirrhosis? J Gastroenterol Hepatol 2000;15:386-390

27. Sheth SG, Flamm SL, Gordon FD, Chopra S. AST/ALT ratio predicts cirrhosis in patients with chronic hepatitis $\mathrm{C}$ virus infection. Am J Gastroenterol 1998;93:44-48

28. Sebastiani G, Alberti A. Non invasive fibrosis biomarkers reduce but not substitute the need for liver biopsy. World $\mathbf{J}$ Gastroenterol 2006;12:3682-3694 
29. Castera L. Assessing liver fibrosis. Expert Rev Gastroenterol Hepatol 2008;2:541-552

30. Manning DS, Afdhal NH. Diagnosis and quantitation of fibrosis. Gastroenterology 2008;134:1670-1681

31. Mehta P, Ploutz-Snyder R, Nandi J, Rawlins SR, Sanderson SO, Levine RA. Diagnostic accuracy of serum hyaluronic acid, FIBROSpect II, and YKL-40 for discriminating fibrosis stages in chronic hepatitis C. Am J Gastroenterol 2008;103:928-936

32. Lackner C, Struber G, Liegl B, Leibl S, Ofner P, Bankuti C, et al. Comparison and validation of simple noninvasive tests for prediction of fibrosis in chronic hepatitis C. Hepatology 2005;41:1376-1382

33. Imbert-Bismut F, Ratziu V, Pieroni L, Charlotte F, Benhamou Y, Poynard T. Biochemical markers of liver fibrosis in patients with hepatitis $\mathrm{C}$ virus infection: a prospective study. Lancet 2001;357:1069-1075

34. Forns X, Ampurdanes S, Llovet JM, Aponte J, Quinto L, Martinez-Bauer E, et al. Identification of chronic hepatitis $\mathrm{C}$ patients without hepatic fibrosis by a simple predictive model. Hepatology 2002;36:986-992

35. Wai CT, Greenson JK, Fontana RJ, Kalbfleisch JD, Marrero JA, Conjeevaram HS, et al. A simple noninvasive index can predict both significant fibrosis and cirrhosis in patients with chronic hepatitis C. Hepatology 2003;38:518-526

36. Patel K, Gordon SC, Jacobson I, Hezode C, Oh E, Smith KM, et al. Evaluation of a panel of non-invasive serum markers to differentiate mild from moderate-to-advanced liver fibrosis in chronic hepatitis C patients. J Hepatol 2004;41:935-942

37. Leroy V, Monier F, Bottari S, Trocme C, Sturm N, Hilleret MN, et al. Circulating matrix metalloproteinases 1, 2, 9 and their inhibitors TIMP-1 and TIMP-2 as serum markers of liver fibrosis in patients with chronic hepatitis C: comparison with PIIINP and hyaluronic acid. Am J Gastroenterol 2004;99:271-279

38. Rosenberg WM, Voelker M, Thiel R, Becka M, Burt A, Schuppan D, et al. Serum markers detect the presence of liver fibrosis: a cohort study. Gastroenterology 2004;127:1704-1713

39. Sud A, Hui JM, Farrell GC, Bandara P, Kench JG, Fung C, et al. Improved prediction of fibrosis in chronic hepatitis $\mathrm{C}$ using measures of insulin resistance in a probability index. Hepatology 2004;39:1239-1247

40. Adams LA, Bulsara M, Rossi E, DeBoer B, Speers D, George J, et al. Hepascore: an accurate validated predictor of liver fibrosis in chronic hepatitis C infection. Clin Chem 2005;51:1867-1873

41. Cales P, Oberti F, Michalak S, Hubert-Fouchard I, Rousselet MC, Konate A, et al. A novel panel of blood markers to assess the degree of liver fibrosis. Hepatology 2005;42:1373-1381

42. Fontana RJ, Kleiner DE, Bilonick R, Terrault N, Afdhal N, Belle $\mathrm{SH}$, et al. Modeling hepatic fibrosis in African American and Caucasian American patients with chronic hepatitis C virus infection. Hepatology 2006;44:925-935

43. Koda M, Matunaga Y, Kawakami M, Kishimoto Y, Suou T, Murawaki Y. FibroIndex, a practical index for predicting significant fibrosis in patients with chronic hepatitis C. Hepatology 2007;45:297-306

44. Callewaert N, Van Vlierberghe H, Van Hecke A, Laroy W, Delanghe J, Contreras R. Noninvasive diagnosis of liver cirrhosis using DNA sequencer-based total serum protein glycomics. Nat Med 2004;10:429-434

45. Lok AS, Ghany MG, Goodman ZD, Wright EC, Everson GT, Sterling RK, et al. Predicting cirrhosis in patients with hepatitis $\mathrm{C}$ based on standard laboratory tests: results of the HALT-C cohort. Hepatology 2005;42:282-292

46. Islam S, Antonsson L, Westin J, Lagging M. Cirrhosis in hepatitis $\mathrm{C}$ virus-infected patients can be excluded using an index of standard biochemical serum markers. Scand J Gastroenterol 2005;40:867-872
47. Vallet-Pichard A, Mallet V, Nalpas B, Verkarre V, Nalpas A, Dhalluin-Venier V, et al. FIB-4: an inexpensive and accurate marker of fibrosis in $\mathrm{HCV}$ infection. Comparison with liver biopsy and fibrotest. Hepatology 2007;46:32-36

48. Fontana RJ, Goodman ZD, Dienstag JL, Bonkovsky HL, Naishadham D, Sterling RK, et al. Relationship of serum fibrosis markers with liver fibrosis stage and collagen content in patients with advanced chronic hepatitis C. Hepatology 2008;47:789798

49. Poynard T, Morra R, Halfon P, Castera L, Ratziu V, Imbert Bismut F, et al. Meta-analyses of Fibrotest diagnostic value in chronic liver disease. BMC Gastroenterol 2007;7:40

50. Shaheen AA, Myers RP. Diagnostic accuracy of the aspartate aminotransferase-to-platelet ratio index for the prediction of hepatitis C-related fibrosis: a systematic review. Hepatology 2007;46:912-921

51. Parkes J, Guha IN, Roderick P, Rosenberg W. Performance of serum marker panels for liver fibrosis in chronic hepatitis $\mathrm{C}$. J Hepatol 2006;44:462-474

52. Halfon P, Bacq Y, De Muret A, Penaranda G, Bourliere M, Ouzan D, et al. Comparison of test performance profile for blood tests of liver fibrosis in chronic hepatitis C. J Hepatol 2007;46:395-402

53. Leroy V, Hilleret MN, Sturm N, Trocme C, Renversez JC, Faure $\mathrm{P}$, et al. Prospective comparison of six non-invasive scores for the diagnosis of liver fibrosis in chronic hepatitis C. J Hepatol 2007; 46:775-782

54. Leroy V, Halfon P, Bacq Y, Boursier J, Rousselet MC, Bourliere $\mathrm{M}$, et al. Diagnostic accuracy, reproducibility and robustness of fibrosis blood tests in chronic hepatitis C: a meta-analysis with individual data. Clin Biochem 2008;41:1368-1376

55. Cales P, de Ledinghen V, Halfon P, Bacq Y, Leroy V, Boursier $\mathrm{J}$, et al. Evaluating the accuracy and increasing the reliable diagnosis rate of blood tests for liver fibrosis in chronic hepatitis C. Liver Int 2008;28:1352-1362

56. Degos F, Perez P, Roche B, Mahmoudi A, Asselineau J, Voitot $\mathrm{H}$, et al. Diagnostic accuracy of FibroScan and comparison to liver fibrosis biomarkers in chronic viral hepatitis: a multicenter prospective study (the FIBROSTIC study). J Hepatol 2010;53:1013-1021

57. Fraser JR, Gibson PR. Mechanisms by which food intake elevates circulating levels of hyaluronan in humans. J Intern Med 2005;258:460-466

58. Piton A, Poynard T, Imbert-Bismut F, Khalil L, Delattre J, Pelissier E, et al. Factors associated with serum alanine transaminase activity in healthy subjects: consequences for the definition of normal values, for selection of blood donors, and for patients with chronic hepatitis C. MULTIVIRC Group. Hepatology 1998;27:1213-1219

59. Cales P, Veillon P, Konate A, Mathieu E, Ternisien C, Chevailler A, et al. Reproducibility of blood tests of liver fibrosis in clinical practice. Clin Biochem 2008;41:10-18

60. Halfon P, Imbert-Bismut F, Messous D, Antoniotti G, Benchetrit $\mathrm{D}$, Cart-Lamy $\mathrm{P}$, et al. A prospective assessment of the interlaboratory variability of biochemical markers of fibrosis (FibroTest) and activity (ActiTest) in patients with chronic liver disease. Comp Hepatol 2002;1:3

61. Imbert-Bismut F, Messous D, Thibaut V, Myers RB, Piton A, Thabut $\mathrm{D}$, et al. Intra-laboratory analytical variability of biochemical markers of fibrosis (Fibrotest) and activity (Actitest) and reference ranges in healthy blood donors. Clin Chem Lab Med 2004;42:323-333

62. Poynard T, Munteanu M, Imbert-Bismut F, Charlotte F, Thabut D, Le Calvez S, et al. Prospective analysis of discordant results between biochemical markers and biopsy in patients with chronic hepatitis C. Clin Chem 2004;10:10 
63. Sandrin L, Fourquet B, Hasquenoph JM, Yon S, Fournier C, Mal F, et al. Transient elastography: a new noninvasive method for assessment of hepatic fibrosis. Ultrasound Med Biol 2003;29:1705-1713

64. Castera L, Forns X, Alberti A. Non-invasive evaluation of liver fibrosis using transient elastography. J Hepatol 2008;48:835-847

65. Roulot D, Czernichow S, Le Clesiau H, Costes JL, Vergnaud AC, Beaugrand M. Liver stiffness values in apparently healthy subjects: influence of gender and metabolic syndrome. J Hepatol 2008;48:606-613

66. Fraquelli M, Rigamonti C, Casazza G, Conte D, Donato MF, Ronchi G, et al. Reproducibility of transient elastography in the evaluation of liver fibrosis in patients with chronic liver disease. Gut 2007;56:968-973

67. Boursier J, Konate A, Guilluy M, Gorea G, Sawadogo A, Quemener E, et al. Learning curve and interobserver reproducibility evaluation of liver stiffness measurement by transient elastography. Eur J Gastroenterol Hepatol 2008;20:693-701

68. Ziol M, Handra-Luca A, Kettaneh A, Christidis C, Mal F, Kazemi F, et al. Noninvasive assessment of liver fibrosis by measurement of stiffness in patients with chronic hepatitis $\mathrm{C}$. Hepatology 2005;41:48-54

69. Castera L, Vergniol J, Foucher J, Le Bail B, Chanteloup E, Haaser M, et al. Prospective comparison of transient elastography, Fibrotest, APRI, and liver biopsy for the assessment of fibrosis in chronic hepatitis C. Gastroenterology 2005; $128: 343-350$

70. Arena U, Vizzutti F, Abraldes JG, Corti G, Stasi C, Moscarella $\mathrm{S}$, et al. Reliability of transient elastography for the diagnosis of advanced fibrosis in chronic hepatitis C. Gut 2008;57:12881293

71. Lupsor M, Badea R, Stefanescu H, Grigorescu M, Sparchez Z, Serban A, et al. Analysis of histopathological changes that influence liver stiffness in chronic hepatitis C. Results from a cohort of 324 patients. J Gastrointest Liver Dis 2008;17:155163

72. Sporea I, Sirli R, Deleanu A, Tudora A, Curescu M, Cornianu $\mathrm{M}$, et al. Comparison of the liver stiffness measurement by transient elastography with the liver biopsy. World J Gastroenterol 2008; 14:6513-6517

73. Shaheen AA, Wan AF, Myers RP. FibroTest and FibroScan for the prediction of hepatitis C-related fibrosis: a systematic review of diagnostic test accuracy. Am J Gastroenterol 2007;102:25892600

74. Talwalkar JA, Kurtz DM, Schoenleber SJ, West CP, Montori VM. Ultrasound-based transient elastography for the detection of hepatic fibrosis: systematic review and meta-analysis. Clin Gastroenterol Hepatol 2007;5:1214-1220

75. Friedrich-Rust M, Ong MF, Martens S, Sarrazin C, Bojunga J, Zeuzem S, et al. Performance of transient elastography for the staging of liver fibrosis: a meta-analysis. Gastroenterology 2008;134:960-974

76. Ganne-Carrie N, Ziol M, de Ledinghen V, Douvin C, Marcellin $\mathrm{P}$, Castera L, et al. Accuracy of liver stiffness measurement for the diagnosis of cirrhosis in patients with chronic liver diseases. Hepatology 2006;44:1511-1517

77. Foucher J, Chanteloup E, Vergniol J, Castera L, Le Bail B, Adhoute X, et al. Diagnosis of cirrhosis by transient elastography (FibroScan): a prospective study. Gut 2006;55:403-408

78. Carrion JA, Navasa M, Bosch J, Bruguera M, Gilabert R, Forns $\mathrm{X}$. Transient elastography for diagnosis of advanced fibrosis and portal hypertension in patients with hepatitis $\mathrm{C}$ recurrence after liver transplantation. Liver Transplant 2006;12:1791-1798

79. Vizzutti F, Arena U, Romanelli RG, Rega L, Foschi M, Colagrande $\mathrm{S}$, et al. Liver stiffness measurement predicts severe portal hypertension in patients with HCV-related cirrhosis. Hepatology 2007;45:1290-1297

80. Ripoll C, Groszmann R, Garcia-Tsao G, Grace N, Burroughs A, Planas R, et al. Hepatic venous pressure gradient predicts clinical decompensation in patients with compensated cirrhosis. Gastroenterology 2007;133:481-488

81. Kazemi F, Kettaneh A, N'Kontchou G, Pinto E, Ganne-Carrie $\mathrm{N}$, Trinchet JC, et al. Liver stiffness measurement selects patients with cirrhosis at risk of bearing large oesophageal varices. J Hepatol 2006;45:230-235

82. Bureau C, Metivier S, Peron JM, Selves J, Robic MA, Gourraud PA, et al. Transient elastography accurately predicts presence of significant portal hypertension in patients with chronic liver disease. Aliment Pharmacol Ther 2008;27:1261-1268

83. Castera L, Le Bail B, Roudot-Thoraval F, Bernard PH, Foucher $\mathrm{J}$, Merrouche $\mathrm{W}$, et al. Early detection in routine clinical practice of cirrhosis and oesophageal varices in chronic hepatitis $\mathrm{C}$ : comparison of transient elastography (FibroScan) with standard laboratory tests and non-invasive scores. J Hepatol 2009;50:59-68

84. Pineda JA, Recio E, Camacho A, Macias J, Almodovar C, Gonzalez-Serrano $\mathrm{M}$, et al. Liver stiffness as a predictor of esophageal varices requiring therapy in HIV/hepatitis $\mathrm{C}$ viruscoinfected patients with cirrhosis. J Acquir Immune Defic Syndr 2009;51:445-449

85. Castera L. Elastography in the non-invasive evaluation of the extent of fibrosis and in the diagnosis of portal hypertension. In Franchis RD, editor. Portal Hypertension V: Proceedings of the Fifth Baveno International Consensus Workshop. WileyBlackwell; 2010. p. 18-27

86. Rigamonti C, Donato MF, Fraquelli M, Agnelli F, Ronchi G, Casazza G, et al. Transient elastography predicts fibrosis progression in patients with recurrent hepatitis $\mathrm{C}$ after liver transplantation. Gut 2008;57:821-827

87. Corradi F, Piscaglia F, Flori S, D'Errico-Grigioni A, Vasuri F, Tame MR, et al. Assessment of liver fibrosis in transplant recipients with recurrent $\mathrm{HCV}$ infection: usefulness of transient elastography. Dig Liver Dis 2009;41:217-225

88. Harada N, Soejima Y, Taketomi A, Yoshizumi T, Ikegami T, Yamashita $\mathrm{Y}$, et al. Assessment of graft fibrosis by transient elastography in patients with recurrent hepatitis $\mathrm{C}$ after living donor liver transplantation. Transplantation 2008;85:69-74

89. Beckebaum S, Iacob S, Klein CG, Dechene A, Varghese J, Baba HA, et al. Assessment of allograft fibrosis by transient elastography and noninvasive biomarker scoring systems in liver transplant patients. Transplantation 2010;89:983-993

90. Carrion JA, Torres F, Crespo G, Miquel R, Garcia-Valdecasas JC, Navasa M, et al. Liver stiffness identifies two different patterns of fibrosis progression in patients with hepatitis $\mathrm{C}$ virus recurrence after liver transplantation. Hepatology 2010;51:2334

91. Cholongitas E, Tsochatzis E, Goulis J, Burroughs AK. Noninvasive tests for evaluation of fibrosis in $\mathrm{HCV}$ recurrence after liver transplantation: a systematic review. Transpl Int 2010;23:861-870

92. Hézode C, Castéra L, Roudot-Thoraval F, Rosa I, Roulot D, Leroy V, et al. Prospective evaluation of liver stiffness dynamics during and after peginterferon alpha-ribavirin treatment in patients with chronic hepatitis C (abstract). J Hepatol 2009;50 Suppl 1:S226

93. Ogawa E, Furusyo N, Toyoda K, Takeoka H, Maeda S, Hayashi J. The longitudinal quantitative assessment by transient elastography of chronic hepatitis $\mathrm{C}$ patients treated with pegylated interferon alpha-2b and ribavirin. Antiviral Res 2009;83:127134 
94. Vergniol J, Foucher J, Castera L, Bernard PH, Tournan R, Terrebonne E, et al. Changes of non-invasive markers and FibroScan values during HCV treatment. J Viral Hepat 2009;16:132-140

95. Masuzaki R, Tateishi R, Yoshida H, Goto E, Sato T, Ohki T, et al. Prospective risk assessment for hepatocellular carcinoma development in patients with chronic hepatitis $\mathrm{C}$ by transient elastography. Hepatology 2009;49:1954-1961

96. Castera L. Liver stiffness and hepatocellular carcinoma: liaisons danger uses? Hepatology 2009;49:1793-1794

97. Castera L, Foucher J, Bernard PH, Carvalho F, Allaix D, Merrouche W, et al. Pitfalls of liver stiffness measurement: a 5 -year prospective study of 13,369 examinations. Hepatology 2010;51:828-835

98. Kettaneh A, Marcellin P, Douvin C, Poupon R, Ziol M, Beaugrand $\mathrm{M}$, et al. Features associated with success rate and performance of FibroScan measurements for the diagnosis of cirrhosis in HCV patients: a prospective study of 935 patients. J Hepatol 2007;46:628-634

99. Lucidarme D, Foucher J, Le Bail B, Vergniol J, Castera L, Duburque C, et al. Factors of accuracy of transient elastography (fibroscan) for the diagnosis of liver fibrosis in chronic hepatitis C. Hepatology 2009:1083-1089

100. Chan HL, Wong GL, Choi PC, Chan AW, Chim AM, Yiu KK, et al. Alanine aminotransferase-based algorithms of liver stiffness measurement by transient elastography (Fibroscan) for liver fibrosis in chronic hepatitis B. J Viral Hepat 2009;16:36-44

101. Coco B, Oliveri F, Maina AM, Ciccorossi P, Sacco R, Colombatto $\mathrm{P}$, et al. Transient elastography: a new surrogate marker of liver fibrosis influenced by major changes of transaminases. J Viral Hepat 2007;14:360-369

102. Sagir A, Erhardt A, Schmitt M, Haussinger D. Transient elastography is unreliable for detection of cirrhosis in patients with acute liver damage. Hepatology 2007;47:592-595

103. Arena U, Vizzutti F, Corti G, Ambu S, Stasi C, Bresci S, et al. Acute viral hepatitis increases liver stiffness values measured by transient elastography. Hepatology 2008;47:380-384

104. Millonig G, Reimann FM, Friedrich S, Fonouni H, Mehrabi A, Buchler MW, et al. Extrahepatic cholestasis increases liver stiffness (FibroScan) irrespective of fibrosis. Hepatology 2008;48:1718-1723

105. Millonig G, Friedrich S, Adolf S, Fonouni H, Golriz M, Mehrabi A, et al. Liver stiffness is directly influenced by central venous pressure. J Hepatol 2010;52:206-210

106. Bosch J. Towards the non-invasive diagnosis of cirrhosis: the nuts-cirrhosis connection. J Hepatol 2009;50:4-6

107. Poynard T, Ingiliz P, Elkrief L, Munteanu M, Lebray P, Morra $\mathrm{R}$, et al. Concordance in a world without a gold standard: a new non-invasive methodology for improving accuracy of fibrosis markers. PLoS ONE 2008;3:e3857

108. Boursier J, Vergniol J, Sawadogo A, Dakka T, Michalak S, Gallois Y, et al. The combination of a blood test and Fibroscan improves the non-invasive diagnosis of liver fibrosis. Liver Int 2009;29:1507-1515

109. Sebastiani G, Vario A, Guido M, Noventa F, Plebani M, Pistis $\mathrm{R}$, et al. Stepwise combination algorithms of non-invasive markers to diagnose significant fibrosis in chronic hepatitis C. J Hepatol 2006;44:686-693

110. Sebastiani G, Halfon P, Castera L, Pol S, Thomas DL, Mangia A, et al. SAFE biopsy: a validated method for large-scale staging of liver fibrosis in chronic hepatitis C. Hepatology 2009;49:1821-1827

111. Bourliere M, Penaranda G, Renou C, Botta-Fridlund D, Tran A, Portal I, et al. Validation and comparison of indexes for fibrosis and cirrhosis prediction in chronic hepatitis $\mathrm{C}$ patients: proposal for a pragmatic approach classification without liver biopsies. J Viral Hepat 2006;13:659-670
112. Bourliere M, Penaranda G, Ouzan D, Renou C, Botta-Fridlund D, Tran A, et al. Optimized stepwise combination algorithms of non-invasive liver fibrosis scores including Hepascore in hepatitis $\mathrm{C}$ virus patients. Aliment Pharmacol Ther 2008;28:458-467

113. Castera L, Sebastiani G, Le Bail B, de Ledinghen V, Couzigou P, Alberti A. Prospective comparison of two algorithms combining non-invasive methods for staging liver fibrosis in chronic hepatitis C. J Hepatol 2010;52:191-198

114. Talwalkar JA, Yin M, Fidler JL, Sanderson SO, Kamath PS, Ehman RL. Magnetic resonance imaging of hepatic fibrosis: emerging clinical applications. Hepatology 2008;47:332-342

115. Huwart L, Sempoux C, Salameh N, Jamart J, Annet L, Sinkus R, et al. Liver fibrosis: noninvasive assessment with MR elastography versus aspartate aminotransferase-to-platelet ratio index. Radiology 2007;245:458-466

116. Yin M, Talwalkar JA, Glaser KJ, Manduca A, Grimm RC, Rossman $\mathrm{PJ}$, et al. Assessment of hepatic fibrosis with magnetic resonance elastography. Clin Gastroenterol Hepatol 2007;5:1207-1213

117. Friedrich-Rust M, Ong MF, Herrmann E, Dries V, Samaras P, Zeuzem $S$, et al. Real-time elastography for noninvasive assessment of liver fibrosis in chronic viral hepatitis. AJR Am J Roentgenol 2007;188:758-764

118. Lewin M, Poujol-Robert A, Boelle PY, Wendum D, Lasnier E, Viallon $M$, et al. Diffusion-weighted magnetic resonance imaging for the assessment of fibrosis in chronic hepatitis C. Hepatology 2007;46:658-665

119. Romero-Gomez M, Gomez-Gonzalez E, Madrazo A, VeraValencia M, Rodrigo L, Perez-Alvarez R, et al. Optical analysis of computed tomography images of the liver predicts fibrosis stage and distribution in chronic hepatitis C. Hepatology 2008;47:810-816

120. Huwart L, Sempoux C, Vicaut E, Salameh N, Annet L, Danse E, et al. Magnetic resonance elastography for the noninvasive staging of liver fibrosis. Gastroenterology 2008;135:32-40

121. Castera L. Acoustic radiation force impulse imaging: a new technology for the noninvasive assessment of liver fibrosis? J Gastrointest Liver Dis 2009;18:411-412

122. Friedrich-Rust M, Wunder K, Kriener S, Sotoudeh F, Richter S, Bojunga $\mathrm{J}$, et al. Liver fibrosis in viral hepatitis: noninvasive assessment with acoustic radiation force impulse imaging versus transient elastography. Radiology 2009;252:595-604

123. Lupsor M, Badea R, Stefanescu H, Sparchez Z, Branda H, Serban A, et al. Performance of a new elastographic method (ARFI technology) compared to unidimensional transient elastography in the noninvasive assessment of chronic hepatitis C. Preliminary results. J Gastrointest Liver Dis 2009;18:303-310

124. Fierbinteanu-Braticevici C, Andronescu D, Usvat R, Cretoiu D, Baicus C, Marinoschi G. Acoustic radiation force imaging sonoelastography for noninvasive staging of liver fibrosis. World J Gastroenterol 2009; 15:5525-5532

125. Boursier J, Isselin G, Fouchard-Hubert I, Oberti F, Dib N, Lebigot $\mathrm{J}$, et al. Acoustic radiation force impulse: a new ultrasonographic technology for the widespread noninvasive diagnosis of liver fibrosis. Eur J Gastroenterol Hepatol 2010;22:1074-1084

126. Takahashi H, Ono N, Eguchi Y, Eguchi T, Kitajima Y, Kawaguchi Y, et al. Evaluation of acoustic radiation force impulse elastography for fibrosis staging of chronic liver disease: a pilot study. Liver Int 2010;30:538-545

127. Castera L, Denis J, Babany G, Roudot-Thoraval F. Evolving practices of non-invasive markers of liver fibrosis in patients with chronic hepatitis $\mathrm{C}$ in France: time for new guidelines? J Hepatol 2007;46:528-529

128. Non invasive methods for the evaluation of hepatic fibrosis/ cirrhosis: an update. www.has-sante.fr (2008)

129. Castera L, Pinzani M. Biopsy and non-invasive methods for the diagnosis of liver fibrosis: does it take two to tango? Gut 2010;59:861-866 